\title{
ChIRonomids of Tropical Rice FiELDS IN THE NORTH MALAYSIAN PENINSUla
}

\author{
Salman Al-Shami ${ }^{1,2}$, Che Salmah Md Rawi ${ }^{1}$, Siti Azizah Mohd Nor $^{1}$ and Abu Hassan Ahmed ${ }^{1}$ \\ ${ }^{1}$ School of Biological Sciences, University Sains Malaysia (USM), 11800 Penang, Malaysia \\ ${ }^{2}$ Biology Department, Faculty of Science, Ibb University, Ibb 70270, Yemen \\ Email: alshami200@yahoo.com
}

\section{Introduction}

Tropical rice fields have a diverse insect fauna, which serves as an important food source for fishes (Ali and Ahmad 1988; Che Salmah and Abu Hassan 2002). Chironomidae have been recorded in rice fields throughout the world including many countries such as India, Australia, and the USA (Martin and Porter 1977; Chaudhuri and Chattopadhyay 1990; Stevens 1995; Stevens et al. 2002, Stevens and Warren 2003). However, in the Malaysian peninsula, very little is known about distribution, taxonomy, biology, and ecology of Chironomidae in rice fields. Nevertheless, some pioneering studies on rice field Chironomidae have been conducted in several rice fields in Kedah and Selangor states (Lim 1990; Rizana 2001; Che Salmah and Abu Hassan 2002; Madziatul 2004).

Knowledge of the Chironomidae fauna in the oriental region is comparatively low compared to the Holarctic and Afrotropical regions (Ashe 1990). Among Chironomidae subfamilies, only Tanypodinae, Orthocladiinae, Chironominae, and Diamesinae are known from the Oriental region (Cranston 2004).

In the southeastern part of Asia very little is known about Chironomidae. Cranston (2004) documented that the first known Chironomidae species from South East Asia was the Javanese Tanypus crux (Wiedemann). Karunakaran (1974) studied Chironomidae in Singapore and contributed more information about Chironomidae in this region. He reported many species from the subfamily Chironominae such as Chironomus apucatus, C. crassiforceps, $C$. costatus, C. stupidus, C. tumidus, C. incertus, Polypedilum convexum, $P$. anticus, and Tanytarsus sp, and from the subfamily Tanypodinae, Tanypus kraatzi.

However, the most valuable information comes from the study of Ashe (1990). A huge number of specimens were obtained during the 1985 Royal Entomological Society "Project Wallace" expedition to Sulawesi, Indonesia. The output of this study was the reporting of around 31 genera of Chironomidae from Sulawesi. Five years later, Murray (1995) reported Conchapelopia insolens as a new species of the subfamily Tanypodinae from Sulawesi. Ashe and O'Connor (1995) reported a new species of Sublettea from northern Sulawesi, Indonesia. Ekrem (2002) investigated Tanytarsus from different areas of South and East Asia.

Bishop (1973) recorded three subfamilies, Chironominae, Tanypodinae, and Orthocladiinae, from the small river Sungai Gombak in peninsular Malaysia. In addition, a single species of Diamesinae was recorded from high elevation (above $3000 \mathrm{~m}$ ) on Mount Kinabalu in Sabah, Malaysia (Cranston 2004). Bishop (1973) pointed out that larvae of the Cryptochironomus complex were the most conspicuous and showed a succession of various types. Siregar et al. (1999) studied the distribution of aquatic insects in five streams in the Kerian River Basin along the Kedah- Perak border. They recorded that the Chironomidae was one of the most dominant families in all streams. Similarly, Che Salmah et al. (1999) recorded that Chironomidae made up most of the collection during the sampling of the aquatic insects In Kedah River Basin.

\section{Materials and methods}

Chironomidae larvae were collected from the rice fields at Bukit Merah Rice Research Station, in Permatang Pauh, Seberang Perai, Pulau Pinang. The larvae were sampled using a long handle aquatic net with $15 \times 15 \mathrm{~cm}$ frame and $30 \mathrm{~cm}$ long net of approximately $300 \mu \mathrm{m}$ mesh size (Storey and Pinder 1985). The aquatic net was dragged for a distance of one meter on the sediment floor collecting chironomid larvae in an area of 15 X $100 \mathrm{~cm}$. The sediment sample with chironomid larvae in it was placed into a plastic bag with a waterproof label of date and location number. The bag was fastened securely with an elastic band and kept in a cool Coleman ${ }^{\circledR}$ chest during transportation to the laboratory.

The sediment sample was washed in a sieve with a mesh size of $300 \mu \mathrm{m}$, and transferred into a 
white plastic basin filled with water. The larvae were sorted and preserved in $80 \% \mathrm{EtOH}$. Chironomid larvae were identified using keys of Cranston (2004), Morse et al. (1994), Merritt and Cummins (1996) and Epler (2001). The sclerotized head capsule was very important for larval identification. Figure 1 shows the common characters of the ventral side of the head capsule of a chironomid larva. The chironomid identifications were verified by Professor Ole A. Sæther, Professor Trond Andersen, Dr. Humberto Mendes (University of Bergen, Norway) and Professor Xinhua Wang (Nankai University, China).

\section{Results}

This study was a preliminary investigation comprising morphological diagnosis of the larval stage of Chironomidae found in rice fields in Permatang Puah, Seberang Perai, Penang, Malaysia. Five species belonging to two subfamilies were identified from this rice field. Three species of the subfamily Chironominae, Chironomus kiiensis Tokunaga, Polypedilum trigonus Townes and Tanytarsus formosanus Kieffer. Two species of subfamily Tanypodinae Clinotanypus sp, and Tanypus punctipennis Meigen were also recorded from this rice field.

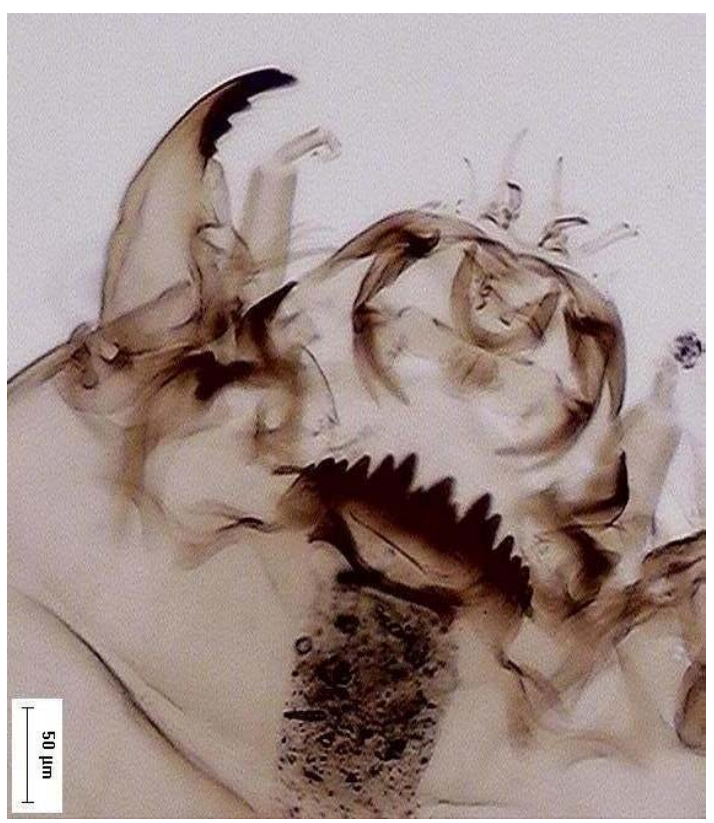

Figure 1. Chironomus kiiensis Tokunaga, 4th instar. Photo: Salman A. Alshami.

\section{Chironominae}

\section{Chironomus kiiensis Tokunaga, Figure 1}

Material examined: 41 larvae, the mean body length was $13.1 \mathrm{~mm}(\mathrm{n}=41)$ Permatang Pauh, Seberang Perai, Penang 2004

Distribution: Japan Hirabayashi et al. (2004), Korea Jeong et al. (2004), Malaysia (present record).

\section{Polypedilum trigonus Townes}

Material examined 18 larvae, the mean body length was $4.8 \mathrm{~mm}(\mathrm{n}=18)$ Permatang Pauh, Seberang Perai, Penang 2004.

Distribution: Tropical water in Borneo (Cranston, 2004), Malaysia (present record).

\section{Tanytarsus formosanus Kieffer}

Material examined: 22 larvae, the mean body length was $5.2 \mathrm{~mm}(\mathrm{n}=22)$ Permatang Pauh, Seberang Perai, Penang 2004

Distribution: Japan Hirabayashi et al. (2004), South and East Asia including Sumatra and Thailand Ekrem (2002), Malaysia (present record).

\section{Tanypodinae}

\section{Clinotanypus sp. Kieffer}

Material examined: 7 larvae, the mean body length was $10.6 \mathrm{~mm}(\mathrm{n}=7)$, Permatang Pauh, Seberang Perai, Penang 2004.

Distribution: The larvae are predators, eurythermic and tolerant to organic pollution (Cranston 2004), and recorded from Bangladesh and India (Chaudhuri and Chattopadhyay 1990) Sumatra Cranston (2004), Malaysia (present record).

\section{Tanypus punctipennis Meigen}

Material examined: 14 larvae, the body length mean was $6.3 \mathrm{~mm}(\mathrm{n}=14)$ Permatang Pauh, Seberang Perai, Penang 2004.

Distribution: The larvae likely to be present in warm shallow pools, especially those with high nutrient loading (Cranston 2004), Malaysia (present record).

\section{Discussion}

The preliminary investigation presented in this paper is based on the morphological diagnosis of the larval stage of Chironomidae found in rice 
fields in Permatang Puah, Seberang Perai, Penang, Malaysia. Five species belonging to two subfamilies were identified from this rice field. Three species of subfamily Chironominae, Chironomus kiiensis Tokunaga, which also has been reported from Korean rice paddies (Jeong et al. 2004), Polypedilum trigonus Townes, one of the common genera in tropical waters including those of Borneo (Cranston 2004) and Tanytarsus formosanus Kieffer. Ekrem (2002) emphasized that the distribution of Tanytarsus formosanus may include many countries including some places in Southeast Asia such as Sumatra and Thailand. Two species of subfamily Tanypodinae Clinotanypus sp, and Tanypus punctipennis Meigen 1818 were recorded from this rice field. Tanypus punctipennis has been reported from the warm shallow pools with high nutrient loadings in Sumatra (Cranston (2004). The populations of these five species vanished when the field was dry.

The agronomic practices change the physical, chemical and biological conditions in the rice ecosystem, making them less favourable for certain organisms and temporarily more favourable for others (Heckman 1979; Bambaradeniya and Amerasinghe 2003). Rice agroecosystem have a great variety of aquatic organisms, well adapted to this temporary and highly manipulated ecosystem that is periodically disrupted by various agricultural practices (Bambaradeniya and Amerasinghe 2003). Temporary drying was a major factor that reduced the abundance of the recorded species.

Chironomidae are known as early colonizers in paddy fields (Che Salmah and Abu Hassan 2002), and appear in the rice field as soon as the water sets in. This was also obvious in this study. Colonization from micro-refugia such as soil cracks or the space among dense rice tillers may have contributed to their prompt appearance in the fields.

The presence of submerged terrestrial plants in the aquatic environment as in the rice field provides a great number of microhabitats for a variety of chironomid taxa (Petr 1972). The most dominant species was Chironomus kiiensis perhaps because of its ability to adapt to the different physical and chemical conditions of the field. Moreover the genus Chironomus has been known to colonize rice fields more rapidly than other taxa (Stevens et al. 2006). Petr (1972) stated that Chironomus abundance seems to be determined by two factors: the presence of fine mud particles for construction of tubes, which they inhabit, and quiet, non-agitated water. Such conditions can be found within the rice field ecosystem.

Chironomidae species are distributed widely in Asian rice fields, and further studies on the taxonomy of all life stages of chironomids in Southeast Asia, in particular in Malaysia, is needed in order to get more accurate identifications.

\section{Acknowledgments}

The authors express their grateful thanks to Prof. Xinhua Wang (Nankai University, China), Prof. Ole A. Sæther, Prof. Trond Andersen and Dr. Humberto Mendes (University of Bergen, Norway) for their valuable help during the identification. Sincere thanks go to also to University Sains Malaysia (USM), Penang, Malaysia for providing facilities for this study.

\section{References}

Ali, A.B. and Ahmad, M. 1988. Water quality in rice field and sump Ponds and its relationship to phytoplankton growth in rice field fish culture system. - Tropical Ecology 29: 63-70.

Ashe, P.D. 1990. Ecology, zoogeography and diversity of Chironomidae (Diptera) in Sulawesi with some observations relevant to other aquatic insects. In Knight, W.J. and Holloway, J.D. (Eds.) Insects in rain forests of South East Asia (Wallacea). Royal Entomological Society, London. pp 261-268.

Ashe, P.D. and O’Connor, J.P. 1995. A new species of Sublettea Roback from Sulawesi. In Peter S. Cranston (Ed.) Chironomids, from gene to ecosystem. CSIRO, Australia. pp 431436.

Bambaradeniya, C.N.B. and Amerasinghe, F.P. 2003. Biodiversity associated with the rice field agroecosystem in Asian countries: A brief review. Working paper 3. Colombo, Sri Lanka: International Water Management Institute (IWMI).

Bishop, J.E. 1973. Limnology of a small Malayan river Sungai Gombak. Dr. W. Junk B.V., The Huge, Netherlands.

Chaudhuri, P.K. and Chattopadhyay, S. 1990. Chironomids of the paddy areas of west Bengal, India (Diptera, Chironomidae). Tijdschrift voor Entomologie 133: 149-195. 
Che Salmah, M.R. and Abu Hassan, A. 2002. Distribution of aquatic insects in relation to rice cultivation phases in a rain fed rice field. Jurnal Biosains 13(1): 87-107.

Che Salmah, M.R., Abu Hassan, A. and Jongkor, G. 1999. Aquatic insect diversities in Kedah, Pinang and Bongor rivers and their potential use as indicator of environmental stress. In Proceedings of River 99, Chan Ngai Weng (Ed.), University Sains Malaysia, pp 335-343.

Cranston, P.S. 2004. Chironomidae, In Yule, C.M. and Yong, H.S. (Eds.) The Freshwater Invertebrates of Malaysia and Singapore. Academy of Sciences, Malaysia. pp 711-735.

Ekrem, T. 2002. A review of selected South and East Asian Tanytarsus v.d. Wulp (Diptera: Chironomidae). - Hydrobiologia 474: 1-39.

Epler, J.H. 2001. Identification manual for the larval Chironomidae (Diptera) of North and South Carolina. Available at the web site, http://www.home.earthlink.net/ johnepler/pub s.html.

Heckman, C.W. 1979. Rice field ecology in Northeastern Thailand. Dr. W. Junk Publishers, The Hague \& Boston, 228p.

Hirabayashi, K., Matsuzawa, M., Yamamoto, M. and Nakamoto, N. 2004. Chironomid fauna (Diptera, Chironomidae) in a filtration plant in Japan. - Journal of the American Mosquito Control Association 20 (1): 74-82.

Jeong, K.Y., Yum, H.Y., Lee, I.Y., Ree, H.L., Hong, C.S., Kim, D.S. and Yong, T.S. 2004. Molecular cloning and characterization of Tropomyosin, a major Allergen of Chironomus kiiensis, a dominant species of nonbiting midges in Korea. - Clinical and Diagnostic Laboratory Immunology 11(2): 320-324.

Karunakaran, L. 1974. A note on parasitized chironomids. - Malaya Natural Journal 28: 32-34.

Lim, R.P. 1990. Effects of pesticides on the aquatic invertebrate community in rice fields.Malaya Nature Journal 45: 336-352.

Madziatul Rosemahanie, M. 2004. Abundance of Chironomidae in paddy field at Station Research Paddy Bukit Merah, Seberang Perai, Pulau Pinang. Undergraduate thesis, University Sains Malaysia, Penang, Malaysia. (In Malay with English abstract).
Martin, J. and Porter, D.L. 1977. Laboratory biology of the rice midges Chironomus tepperi Skuse (Diptera: Nematocera): Mating behaviour, productivity and attempt at hybridization. - Journal of the Australian Entomological Society 16: 411-416.

Merritt, R.W. and Cummins, K.W. 1996. An introduction to the aquatic insects of North America. Third Edition. Kendall/Hunt Publication Co. 862p.

Morse, J.C., Lianfang, Y. and Lixin, T. 1994. Aquatic insect of China useful for monitoring water quality. Hohai University Press, Najing, China. 570p.

Murray, D.A. 1995. Conchapeloia insolens, new species of Tanypodinae (Chironomidae: Diptera) from Sulawesi. In Cranston, P.S. (Ed.) Chironomids from gene to ecosystem. CSIRO, Australia. pp 417-424.

Petr, T. 1972. Benthic fauna of a tropical manmade lake (Volta Lake, Ghana 1965-1968). Archiv für Hydrobiologie 70(4): 484-533.

Rizana, M.S. 2001. Abundance and diversity of aquatic insects in rice fields of MADA, Kedah. Undergraduate thesis, University Sains Malaysia, Penang, Malaysia (In Malay with English abstract).

Siregar A. Z., Che Salmah M. R., Abu Hassan A. (1999). Distribution of aquatic insect and its implication on water quality in the Kerian River basin, Kedah-Perak, Malaysia. In Proceedings of River 99, Chan Ngai Weng (Ed.), University Sains Malaysia, pp 329-334.

Stevens, M.M. 1995. Biology control of Chironomus tepperi Skuse, A pest of rice in New South Wales. In Cranston, P.S. (Ed.) Chironomids from gene to ecosystem. CSIRO, Australia. pp 235-239.

Stevens, M.M. and Warren, G.N. 2003. Colonization of rice crops by chironomids in southern Australia (Abstract). In Ferrington Jr., L.C. XV International symposium on Chironomidae, University of Minnesota, 2-14 August 2003, Minnesota, USA.

Stevens, M.M., Ali, A., Helliwell, S., Schiller, L.J. and Hansen, S. 2002. Comparison of two bioassay techniques for assessing the acute toxicity of pesticides to chironomid larvae (Diptera: Chironomidae). - Journal of American Mosquito Control Association 18(2): 119-125. 
Stevens, M.M., Helliwell, S. and Cranston, P.S. 2006. Larval chironomid communities (Diptera: Chironomidae) associated with establishing rice crops in New Southern Wales, Australia. - Hydrobiologia 556(1): 317-325.
Storey, A.W. and Pinder, L.C.V. 1985. Mesh-size and efficiency of sampling of larval Chironomidae. - Hydrobiologia 124: 193-197. 